\title{
A study of low power laser on the regenerative process of Girardia tigrina (Girard,1850) (Turbellaria; Tricladida; Dugesiidae)
}

\author{
Lopes, KAR. ${ }^{\mathrm{a} *}$, Campos Velho, NMR. ${ }^{\mathrm{a}}$ and Munin, E. ${ }^{\mathrm{b}}$ \\ ${ }^{a}$ Centro de Estudos da Natureza - CEN, Universidade do Vale do Paraíba - UNIVAP, \\ Av. Shishima Hifumi, 2911, CEP 12244-000, São José dos Campos, SP, Brazil \\ bUniversidade Camilo Castelo Branco - Unicastelo, \\ Rod. Presidente Dutra, Km 138, CEP 12247-004 São José dos Campos, SP, Brazil \\ *email: nvelho@univap.br \\ Received February 15, 2007 - Accepted July 27, 2007 - Distributed May 31, 2009
}

(With 6 figures)

\begin{abstract}
The mechanism of regeneration does not start to restore the wound until its corresponding epimorphic phase. A bioestimulation of tissues and cells by laser radiation depends on the wavelength, on the dose, and on the intensity of the light. The goal of this work was to verify the effect of the low power laser at $660 \mathrm{~nm}$ on the regenerative process of Girardia tigrina. The specimens were maintained in the laboratory under a temperature ranging from $19^{\circ}$ up to $24{ }^{\circ} \mathrm{C}$ for 21 days. The planarians were anesthetized by placing them on ice and then cut them with a scalpel. The three treatments were as following: animals individually irradiated with 14 sessions with 1 minute duration (treatment 1), 14 sessions with 3 minutes duration (treatment 2), and without irradiation (control). The planarians were amputated and divided in three study treatments: a control group (without radiation), and two other treatments: irradiated for 1 minute, and irradiated for 3 minutes. The animals were irradiated with diode laser $(660 \mathrm{~nm})$ with $3.3 \pm 0.3 \mathrm{~mW}$ of power, using $0.94 \mathrm{~mW} \cdot \mathrm{mm}^{-2}$ power density for each irradiation procedure. During the experiment, 14 irradiation sessions were undertaken. The specimens were fixed in Bouin, and stained with hematoxyline and eosin. From observation and histological analysis, it was possible to assess the effects of interaction between laser and tissue. The head fragment after 1 minute of irradiation presented a better organized tissue scheme, when compared with the other treatments. Aspects of the body fragments submitted to 3 minutes of light treatment were very similar to fragments that had not been injured. It can be concluded that there are changes in the quality of regeneration when treated with low power laser under the conditions mentioned above.
\end{abstract}

Keywords: regeneration, Girardia tigrina, laser, Dugesiidae, histology.

\section{Um estudo de laser de baixa potência no processo regenerativo de Girardia tigrina (Girard,1850) (Turbellaria; Tricladida; Dugesiidae)}

\begin{abstract}
Resumo
O mecanismo de regeneração não restaura a ferida até sua fase epimórfica correspondente. A bioestimulação de tecidos e células por radiação laser depende do comprimento de onda, da dose e intensidade de luz. O objetivo deste trabalho foi verificar o efeito do laser de baixa potência $(660 \mathrm{~nm})$ no processo regenerativo de Girardia tigrina. Estes vermes têm uma elevada capacidade de regeneração. Os espécimes foram mantidos em laboratório sob uma temperatura de $19^{\circ}$ a $24^{\circ} \mathrm{C}$ por 21 dias. As planárias foram anestesiadas com gelo e amputadas com bisturi. Os 3 tratamentos foram compostos de: animais individualmente irradiados com 14 sessões de 1 minuto de duração (tratamento 1), com 14 sessões de três minutos de duração (tratamento 2) e não irradiados (controle). Elas foram irradiadas com laser diodo $(660 \mathrm{~nm}) 3,3 \pm 0,3 \mathrm{~mW}$ potência, usando $0.94 \mathrm{~mW} \cdot \mathrm{mm}^{-2}$ de densidade de potência para cada irradiação. Durante o experimento foram realizadas 14 sessões. Os espécimes foram fixados em Bouin e corados com hematoxilina e eosina. Com base nas observações e análise histológica, foi possível avaliar os efeitos da interação entre laser e tecido. $\mathrm{O}$ fragmento cabeça após 1 minuto de irradiação mostrou um tecido melhor organizado quando comparado com outros tratamentos. Os aspectos dos fragmentos corpo após 3 minutos de irradiação foram muito similares para os fragmentos que não sofreram injúria. Existem mudanças na qualidade de regeneração quando tratadas com laser nas condições acima mencionadas.
\end{abstract}

Palavras-chave: regeneração, Girardia tigrina, laser, Dugesiidae, histologia. 


\section{Introduction}

The principles underlying regeneration in planarians have been explored for over 100 years through surgical manipulations and cellular observations. Planarian regeneration involves the generation of new tissue at the wound site via cell proliferation (blastema formation), and the remodeling of pre-existing tissues to restore symmetry and proportion (morphallaxis). Because blastemas do not replace all tissues following most types of injuries, both blastema formation and morphallaxis are needed for complete regeneration (Reddien and Alvarado, 2004).

The regeneration of Turbellaria has an outstanding characteristic. The mechanism of regeneration does not start to restore the wound until its corresponding epimorphic phase (Hauser and Santos, 1985; Hori, 1997). This process commences with the formation of blastema, which is composed by neoblast which are undifferentiated and totipotent cells. Planaria have an epidermis of cube cells which are located on an elastic basal membrane.

The choice of planarians as system to address the problem of regeneration is based upon: their remarkable developmental plasticity; the rapidity of their regenerative response; the ease with which they can be cultured in the laboratory; and the stem cell population that gives rise to their regenerative abilities. The planarian, a small flatworm, can be cut into pieces as small as one- $279^{\text {th }}$ of the whole, and entire new worms will grow from the segments (Stamen, 2002). In uninjured planaria, neoblasts are distributed throughout the parenchyma (mesenchyme), and only mitotic cells serve as the source of replacement cells during tissue renewal (Newmark, 2007).

In the epidermis there are deeply located rhabdites and unicell glands which open to the surface. The layers of circular, longitudinal, diagonal and dorsoventral muscular fibers are located under the basal membrane (Ball, 1974). The spaces between the muscles and the organs are filled with mesenchyma and parenchyma. In the parenchyma there are free form cells which regenerate by mitosis. The digestive system is composed of columnar epithelium which is a derivative of the endoderm (Raven and Johnson, 1990).

The regeneration can also be found in vertebrates. Salamanders can regrow multiple types of tissue to make complete structures like limbs. Urodeles amphibians newts and salamanders - are "champions of regeneration". Uniquely among vertebrates, they can regrow a wide variety of lost or damaged body parts including limbs, tails, parts of the eye, and even large chunks of the heart. In each case, they achieve this by first dedifferentiating neighbourings cells (Pearson, 2001).

The interaction of low power laser radiation with the tissue increases the cell metabolism, the chemiotax, the vascularization, and other processes (Lopes and Brugnera, 1998; Efendiev et al.,1992). The effects of stimulation by low power laser depend on the wavelength, the dose, and the intensity of the light used in the irradiation process (Sommer et al., 2001). This work aims to analyze the effects of low power laser radiation on the regenerative process.

Irradiation of cells at certain wavelengths can also activate some of the native components. This type of reaction is believed to form the basis for low-power laser effects (Karu, 1987; Karu, 1989; Smith, 1991).

The low power lasers have been used with different activator materials, wavelengths, powers, frequencies, and energy densities to accelerate wound healing. Irradiation with such lasers changes the behavior of several cells, increasing the vascular formation, the production of collagen, fibroblasts, and epithelium. More studies are necessary for a complete understanding of the photobiological effects promoted by the use of these lasers (Bourguignon-Filho et al., 2005). The therapy with low power laser is a technique able to speed up the restoration of the traumatized biological tissues (Karu, 1999).

\section{Material and Methods}

The specimens were young organisms (Girardia (=Dugesia) tigrina (Girard, 1850)) collected from their natural habitat, a river Paraíba do Sul localizated in the city of Jacareí, state of São Paulo, Brazil. The worms were fed fresh bovine liver once a week. An amount of 30 worms measuring from 0.5 up to $1 \mathrm{~cm}$ in length were cut transversally at level just below of the auricles.

These were maintained in the laboratory at a temperature ranging from 19 up to $24^{\circ} \mathrm{C}$. The specimens were selected taking into account their normal morphology and absence of wounds.

They were divided in 3 treatments of ten specimens: 1) control group (non-irradiated); 2) irradiated group-1 (irradiation for 1 minute); and 3) irradiated group-2 (irradiation for 3 minutes), adopting as a rule, a 24 hours interval between treatment sections. Prior to the irradiation procedure, the planarians were kept in plastic recipients containing water from an artesian well.

The specimens were placed on filter paper over an ice block to anesthetise them prior to their amputation (inside a Petri dish). The amputation of the head was undertaken using a scalpel at the post auricular region. The size of these worms requires the use of a stereomicroscope system, coupled to a video camera for that procedure. The specimens were irradiated 48 hours after amputation. The pre and post auricular fragments were removed from the recipient, and then the fragments were placed in a Petri dish (containing $4 \mathrm{~mL}$ of water from an artesian well) to check for any defects. The fragments were then irradiated with the aid of a stereomicroscope system attached to a video camera.

The irradiation procedure was as follows: after amputation, head and body fragments were irradiated with the laser beam applied perpendicular to the Petri plate surface. After the $14^{\text {th }}$ irradiation session, transversal histological cuts were undertaken.

14 irradiation sessions were applied over a period of 22 days on head and body planarian fragments using 
the same laser power density. The power emitted by the laser was measured with a silicon sensor (Newport trade mark). In order to avoid excessive power fluctuations, the laser batteries were changed periodically when their voltage decreased to $1.4 \mathrm{~V}$. This voltage was constantly monitored by a digital voltmeter model ET - 2070, during the irradiation sessions. The optical power was maintained at $3.3 \pm 0.3 \mathrm{~mW}$.

The spatial dimensions of the laser beam were measured using the conventional method of moving the laser source: the beam was transversally moved over two perpendicular axes, where one small opening coupled to a silicon detector with a plain sensor area of $10 \mathrm{~mm}$ diameter containing a front mask with a hole of $100 \mu \mathrm{m}$. The laser source was placed on a mobile base with a micrometer with resolution of one hundredth milimeter. The electrical signal from the sensor was measured at each $0.1 \mathrm{~mm}$ (by a digital voltmeter brand Minipa - model ET-2070). The measurement was taken along each transversal axis of the optical beam - see Figure 1 .

Beam power density is better estimated observing the beam image through a video camera. A rectangular

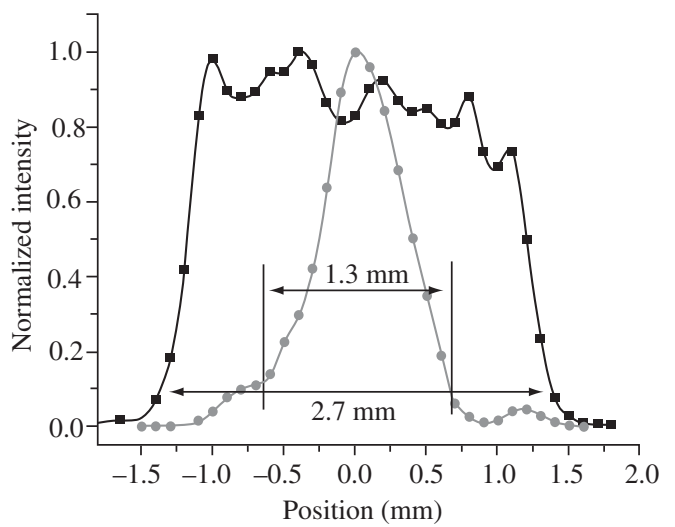

Figure 1. Normalized spatial distribution measurement of the beam intensity delivered by the laser diode. The two curves were taken on perpendicular axes. surface for the beam image can be assumed as a good estimate for computing purpose. The beam transversal dimensions were taken from $10 \%$ of the peak value, the beam area was approximately $1.3 \times 2.7 \mathrm{~mm}^{2}$ (Figure 1) while beam power density was $0.94 \mathrm{~mW} \cdot \mathrm{mm}^{-2}$.

The specimens of the 3 study groups were fixed in Bouin solution for 50 hours. Bouin solution was used as a fixative (Vara et al., 2001) as it moderately contracts the head and body resulting in more uniform histology samples (Silva et al., 1997). The fixative was removed using ammonium hydroxide with distilled water in a Petri dish and incubated for 30 minutes.

The fixed specimens were dehydrated in 5 consecutive baths of ethyl alcohol 50, 60, 70, 80, 95, and 100\%, per hour. The transparency was placed in 2 xylol baths for 2 hours. The fragments were then placed in paraplast in liquid form at $60{ }^{\circ} \mathrm{C}$ for 4 hours following the definitive inclusion. After solidification, transversal cuts were performed by a microtome Leica RM 2135, at $7 \mu \mathrm{m}$ thickness and fixed to a microscope slide. Considering head fragment and the body fragment together with 10 planarians per group (corresponding to the 30 pieces), 107 sections were carried out at each group. The cuts were then stained with hematoxylin and eosin.

Before the definitive assembly, the slides were analyzed with a microscope to verify the quality of the cut plus the seal of the Canadian Balsam. The histology samples were photo documented using an Olympus ${ }^{\circledR} \mathrm{CH} 30$ microscope connected to a camera.

\section{Results}

\subsection{Body fragment}

The histological analysis has been focused to those transversal cuts at level just below to the auricles. The histological cut of the control group was homogeneous. It was possible to identify the epidermis containing rhabdites and glands; lumen of the pharynx; part of the pharynx cavity, and bowel lumen (see Table 1 and Figure 2).

Table 1. Structures for the head and body fragments: control and irradiated groups.

\begin{tabular}{lcccccc}
\hline & \multicolumn{2}{c}{ Structure } & \multicolumn{2}{c}{ Group-1 } & \multicolumn{2}{c}{ Group-2 } \\
\cline { 2 - 7 } & Head & Body & Head & Body & Head & Body \\
\hline Epidermis & $*$ & 1 & 1 & 1 & 1 & 1 \\
Rhabdites & $*$ & 1 & 1 & 1 & 0 & 1 \\
Unicell glands & $*$ & 1 & 0 & 0 & 0 & 0 \\
Layers of longitudinal, muscular fibers & $*$ & 0 & 1 & 0 & 0 & 1 \\
Parenchyma & $*$ & 0 & 0 & 0 & 0 & 1 \\
Pharynx cavity & $*$ & 1 & 0 & 0 & 0 & 0 \\
Pharynx lumen & $*$ & 1 & 1 & 1 & 0 & 1 \\
Cavity bowel lumen & $*$ & 1 & 0 & 0 & 0 & 1 \\
Gastrovascular cavity & $*$ & 0 & 0 & 1 & 0 & 0 \\
\hline
\end{tabular}

1 = observed; 0 = not observed; $*$ dead. 


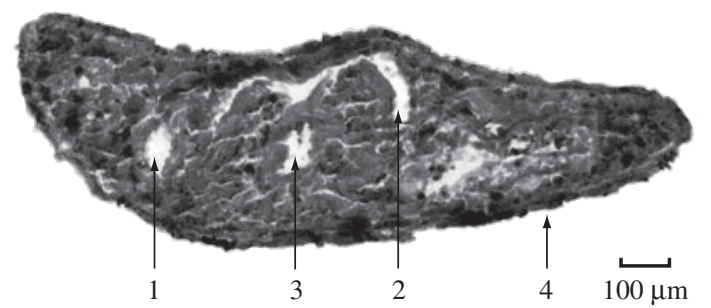

Figure 2. Body fragment for the control group: cavity bowel lumen (1), part of the pharynx cavity (2), pharynx lumen (3), epidermis containing rhabdites and glands (4).

Figure 3 shows the histological cut of group-1. The tissue architecture is more identifiable. The epidermis containing the rhabdites can be seen, together with the gastrovascular cavity and the lumen of pharynx. The surrounding border of the cut can also be seen

For group-2, the identifiable structures were: epidermis and rhabdites, layer of longitudinal muscular fibers, lumen of pharynx, pharynx cavity, gastrovascular cavity, parenchyma and bowel lumen - see Figure 4.

\subsection{Head fragment}

Group-1 shows the following structures: pharynx lumen, layer of longitudinal muscular fibers and epidermis with rhabdites (see Table 1 and Figure 5).

Finally, with group-2 it is only possible to identify the epidermis (see Figure 6).

There is no figure for the control group, as all head fragments from this group did not survive.

\section{Discussion}

In recent years, the interest in planarians as a model system for the study of metazoan regeneration, adult stem cell biology, and the evolution of metazoan body plans has been growing steadily (Robb and Alvarado, 2002). Planarians are organisms that have three tissue layers and tissues with distinct organs. These animals have key anatomical features (mesoderm, central nervous system (CNS) and excretory system) that might have been platforms for the evolution of the complex and highly organized tissues and organs found in higher organisms. However, the phylogenetic status of the Platyhelminthes has always been controversial (Newmark and Alvarado, 2002). For the present study, histology analysis was performed for comparison of the impact of the radiation effect during the regeneration process.

\subsection{Body fragment}

The identified structures in the histology sample of the control group confirm what was described by Gills and Haro (2001), being the distinguished structures pharynx cavity, pharynx lumen, gastrovascular cavity, epidermis, gastrodermis, layer of parenchyma.

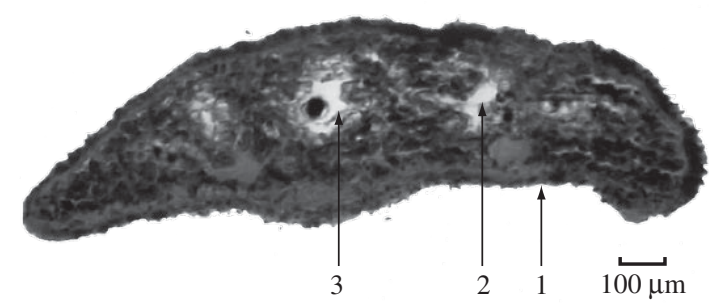

Figure 3. Body fragment for the 1 minute-treated group: epidermis and rhabdites (1), pharynx lumen(2), gastrovascular cavity (3).

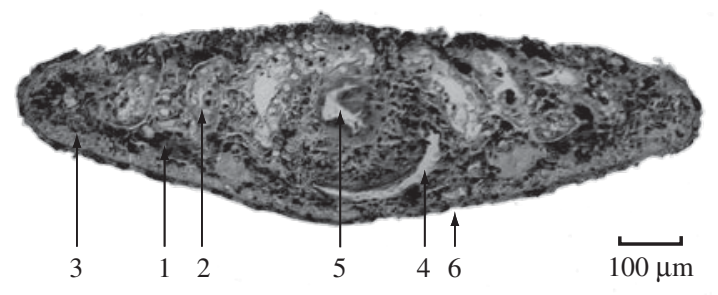

Figure 4. Body fragment for the 3 minutes-treated group: cavity pharynx (1), pharynx lumen (2), epidermis and rhabdites (3), parenchyma (4), bowel lumen (5), layer of longitudinal muscular fibers (6).

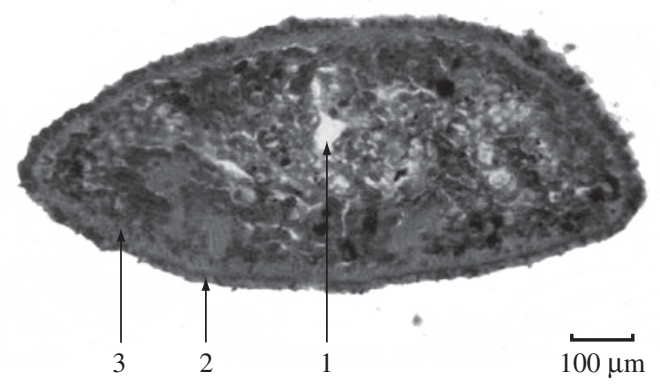

Figure 5. Head fragment for the 1 minute-treated group: pharynx lumen (1), epidermis and rhabdites (2), layer of longitudinal muscular fibers (3).

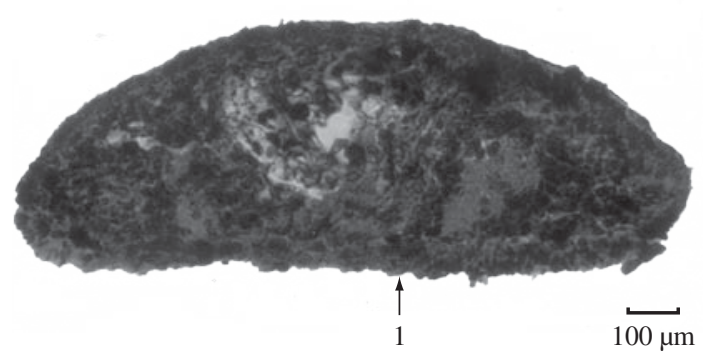

Figure 6. Head fragment for the 3 minute-treated group: epidermis (1). 
In the epidermis, the rhabdites (which have an uncertain function), and unicell glands (which are deeply located and open to the surface producing mucus) are visible. Below the epidermis, the basal membrane is located, where there are layers of longitudinal, dorsoventral, diagonal and circular muscular fibers (Raven and Johnson, 1990).

In the histology samples for groups 1 and 2, the epidermis, rhabdites and unicell glands can be observed. It was also noted that the tissue architeture was better organized in groups- 2 than groups- 1 and the control group. This may be due to laser tissue interaction which produced a better repair and tissue organization, by the absorption of radiation by the cells or by its inherent chromophores, causing alteration in its metabolism in both, superficial and deep tissue (Giese, 1980; Lobko et al., 1985; Mester et al., 1985; Svaasand, 1990). In addition, low power lasers accelerate wound healing, changing the behavior of several cells, increasing the vascular formation, the production of collagen, fibroblasts and epithelium (Bourguignon-Filho et al., 2005 (Anderson and Parrish, 1982; Jori, 1980).

The results for the body fragments show better effects in group-2, illustrating that the stimulation with low power laser has an effect dependent on the applied radiation dose (Fedoseyeva et al., 1988). Irradiation of cells at certain wavelengths can also activate some of the native components. This type of reaction is believed to form the basis for low-power laser effects (Karu, 1987; Smith, 1991).

\subsection{Head fragment}

For this fragment, it was possible to observe the converse, where the histological cut of group- 1 shows a better organized tissue architecture than group-2. This may be due to the presence of ocellus in the head, as they are photoreceiver structures (Azuma, 1997; Azuma et al., 1999). A phototaxis assay system to analyze light response recovery during head regeneration determined that light evasion is markedly re-established 5 days after amputation (Inoue et al., 2004).

Similar to the planarians, regeneration is a process that can be found in other animal groups. Salamanders, starfish, tentacle-waving polyps and zebrafish - many and varied are the organisms that can regenerate new head, limbs, internal organs or other body parts, if the originals are lost or damaged (Pearson, 2001).

In group-1, it is possible to notice pharynx lumen, layer of longitudinal muscular fibers, epidermis and rhabdites. For group-2, only the epidermis is observed.

The radiation from the diode laser $(660 \mathrm{~nm})$ of $0.94 \mathrm{~mW} . \mathrm{mm}^{-2}$ power density influences the regeneration process of G. tigrina (Girard, 1850). This is confirmed by the histological analysis. The body fragment irradiated for 3 minutes showed better tissue architecture allowing the identification of a larger number of structures. The head fragment of group-1 showed better quality for identification of the structures compared to group-2.

The laser radiation with the applied power density was not lethal to G. tigrina.
The present study indicated that for groups 1 and 2 the body fragment shows the following structures: epidermis, rhabdites, and unicell glands. The head fragment also presented some structures cited before: epidermis, and rhabdites. However, different structures were also identified: pharynx lumen, and a layer of longitudinal muscular fibers.

For the regeneration process related to the body fragment, group-2 presented better tissue architecture (3 minutes of laser exposure) compared to group-1 and the control group. However, considering the head fragment, group-1 (1 minute of laser exposure) presented better tissue architecture than group-2. The control group for the head fragment has died during the experiment.

The general conclusion is that the low power laser has influenced in the regenerative process of planarians with the optical radiation treatment.

Acknowledgements - The financial support of the Fundação de Amparo à Pesquisa do Estado de São Paulo - FAPESP, trough the grant \#2001/12754-2 is acknowledged. The authors are grateful to the professor Cristina Pacheco Soares from the Histological Analysis Group, IPD (Institute of Research and Development) - UNIVAP.

\section{References}

ANDERSON, RR. and PARRISH, JA., 1982. Optical properties of human skin. In REGAN, JD. and PARRISH, JA. (Eds.). The science of photomedicine. New York: Plenum. p. 147-195.

AZUMA, K., 1997. Light-induced changes of extracelular volume in a planarian ocelus. Comparative Biochemistry and Physiology. vol. 117A, no. 1, p. 155-159.

AZUMA, K., IWASAKI, N. and OHTSU, K., 1999. Absortion spectra of planarian visual pigments and two states of the metarhodopsin intermediates. Photochemistry and photobiology, vol. 69 , no. 1 , p. 99-104.

BALL, RI., 1974. A contribution to the phylogeny and biogeography of the freshwater Triclads (Platyhelminthes: Turbellaria). In RIESER, NM. and MORSE, MP. (Eds.). Biology of the Turbellaria. New York: Mc. Graw Hill. p. 339-401.

BOURGUIGNON-FILHO, AM., FEITOSA, ACR., BELTRÃO, GC. and PAGNONCELLI, RM., 2005. Utilização do laser de baixa intensidade no processo de cicatrização tecidual: revisão de literatura. Revista Portuguesa de Estomatologia, Medicina Dentária e Cirurgia Maxilofacial, vol. 46, no. 1, p. 37-43.

De VRIES, EJ. and SLUYS, R., 1991. Phylogenetic relationships of the genus Dugesia. Journal of Zoology London, vol. 223, no. 1, p. 103-116.

EFENDIEV, AI., TOLSTYKH, PI., DADASHEV, AI. and AZIMOV, SA.,1992. Increasing the scar strenght after preventive skin radiation with low-intensity laser. Klin Klir, vol. 1 , p. 23-25.

FEDOSEYEVA, GE., KARU, TI., LYAPUNOVA, TS., POMOSHNIKOVA, NA. and MEISSEL, MN., 1988. The activation of yeast metabolism with He-Ne irradiation - I: protein synthesis in various cultures. Lasers in the Life Sciences, vol. 2, no. 2, p. 137-146. 
GIESE, AC., 1980. Photobiology and a problems. In PRATESI, R. and SACHI, CA. (Eds.). Lasers in photomedicine and photobiology. New York: Spring Verlag. p. 26-30

GILLS, R. and HARO, RJ., 2001. Departament of biology of University Winconsi. Available from: <http://bioweb.uwlax. edu/zoolab/Table of contem/ Lab 4b/planaria 2/ planaria.html>. Access in: 5 de Novembro de 2001.

HAUSER, J. and SANTOS, WH., 1985. Studies of regeneration in Dugesia anderlani Kawakatsu et Hauser, 1983. 1. Part Regeneration of amputed head. Morphological study. Acta Biologica Leopoldensia, vol. 2, no. 2, p.163-174.

HORI, I., 1997. Cytological approach to morphogenesis in the planarian blastema. II The effect of Neuropeptides. Journal of Submicroscopic Cytology and Pathology, vol. 29, no. 1, p. 91-97.

INOUE, T., HIROSHI, K., KEIJI, O., YOSHIHIKO, U., MASAKI, S., SANCHEZ, AA., KIYOKAZU, A., 2004. Morphological and functional recovery of the planarian photosensing system during head regeneration. Zoological Science, vol. 21, no. 3, p. 275-283.

JORI, G., 1980. The molecular biology of photodynamic action. In PRATESI, R. and SACCHI, CA. (Eds.). Laser Photomedicine Photobiology. New York: Sprinter Verlag. p. 58-66.

KARU, TI., 1987. Photobiological fundamentals of low-power laser therapy. IEEE Journal of Quantum Electronics, vol. QE-23, no. 10 , p. 1703-1717.

1989. Laser bioestimulation: a photobiological Phenomenon. Journal Photochemistry and Photobiology, vol. 3, no. 4, p. 638-639.

1999. Primary and secondary mechanism of an action of visible to near I-R radiation on cells. Journal of Photochemistry and Photobiology B: Biology, vol. 49, no. 1, p. 1-1

LOBKO, VV., KARU, TI. and LETHOKOV, VS., 1985. Is the coherence of low - intensity laser light essential for its effects on biological objects?. Biofizika, vol. 30, no. 2, p. 366-371.

LOPES, LA. and BRUGNERA, AJ., 1998. Aplicações do laser não-cirúrgico. In BRUGNERA, AJ. and PINHEIRO, ALB. (Eds.). Lasers na odontologia moderna. São Paulo: Pancast. p. $100-120$.

MESTER, E., MESTER, AF. and MESTER, A., 1985. The biomedical effects of laser application. Lasers in Surgery and Medicine, vol. 5, no. 1, p. 31-39.
NEWMARK, PA. and ALVARADO, AS., 2002. Not your father's planarian: a classic model enters the era of functional genomics. Nature Reviews Genetics, vol. 3, p. 210-219.

NEWMARK, PA. Newmark laboratory Planarian biology. Available from: <http://www.life.uiuc.edu/newmark/planarians. html>. Access in: 25 de Maio de 2007.

PEARSON, H., 2001. The regeneration gap. Nature, vol. 414, no. 6862 , p. $388-390$.

RAVEN, PH. and JOHNSON, GB., 1990. Biology. Dubuque: WCB. p. $850-851$.

REDDIEN, PW. and ALVARADO, AS., 2004. Fundamentals of planarian regeneration. Annual Review of Cell and Developmental Biology, vol. 20, p. 725-757.

ROBB, SMC. and ALVARADO, AS., 2002. Identification of immunological reagent for use in the study of freshwater planarians by means of hole - mount immunoflorescence and confocal microscopy. Genesis: Journal of Genetics and Development, vol. 32, no. 4, p. 293-298.

SILVA, NMS., LEAL-ZANCHET, AM. and HAUSER, J., 1997. Analysis of the efficiency of different solutions for the fixation of Girardia tigrina (TURBELLARIA, TRICLADIDA, PALUDICOLA). Brazilian Journal Morphology Science, vol. 14 , no. 2, p. 271-274.

SMITH, KS., 1991. The photobiological basis of low-level laser radiation therapy. Laser Therapy, vol. 3, no. 1, p. 19-25.

SOMMER, AP., PINHEIRO, ALB., MESTER, AR., FRANKE, RP. and WHELAN, HT., 2001. Bioestimulatory windows in low-intensity laser activation: lasers, scanners, and NASA's light-emitting diode array system. Journal of Clinical Laser and Medicine and Surgery, vol. 19, no. 1, p. 23-29.

STAMEN, E., 2002. Missing Limb?: salamander may have answer, health. The New York Times. Available from: http://eric. stamen.com/net/nyTimes_092302b.html. Access in: 25 de Maio de 2007

SVAASAND, LO., 1990. Bioestimulation with low-intensity lasers physics or metaphisics?. Nordisk Medicine, vol. 105, no. 3, p.72-75.

VARA, DC., LEAL-ZANCHET, AM. and LIZARD-DAUDT, HM., 2001. Histological processing techniques for the study of Dugesiidae development (Plateyhelminthes; Tricladida, Paludicola). Revista Brasileira de Biologia, vol. 61, no. 2, p. 341-345. 